\title{
PENGARUH PELATIHAN KEPEMIMPINAN DIRI UNTUK MENINGKATKAN KEPUASAN KERJA KARYAWAN
}

\author{
Ike Agustina \\ Fakultas Psikologi dan IImu Sosial Budaya Universitas Islam Indonesia Yogyakarta \\ E-mail: ike.agustina@uii.ac.id
}

Moch. Bachroni

Fakultas Psikologi Universitas Gadjah Mada Yogyakarta

\begin{abstract}
One of the factors that influence the employee's performance is job satisfaction. The purpose of this study was to examine the effect of self-leadership training to increase the employee's job satisfaction. Participants of this research were non-academic employees of a private university in Yogyakarta. The comparative study was conducted toward the experimental group $(N=11)$ and control group $(N=11)$. The study used the untreated control group design with pre-test and post-test model. The experimental group was the one who received self-leadership training, while the control group did not receive the intervention. Hypothesis test used non-parametric statistical Mann-Whitney $U$ indicated that there is no significant difference of job satisfaction between these two groups ( $Z=$ 0.033, $p=0.974 ; p>0.05$ ).
\end{abstract}

Key words: Self-leadership training, job satisfaction

\begin{abstract}
ABSTRAK
Salah satu faktor yang turut memengaruhi unjuk kerja karyawan adalah kepuasan kerja. Tujuan dari penelitian ini adalah untuk mengetahui pengaruh dari pelatihan kepemimpinan diri terhadap peningkatan kepuasan kerja karyawan. Partisipan penelitan ini adalah karyawan non-akademik sebuah universitas swasta di Yogyakarta. Studi komparasi dilakukan antara kelompok eksperimen $(\mathrm{N}=11)$ dan kelompok kontrol $(\mathrm{N}=11)$. Desain penelitian menggunakan the untreated control group design with pre-test and post-test. Pada kelompok eksperimen diberikan pelatihan kepemimpinan diri, sedangkan kelompok kontrol tidak. Hasil uji hipotesis menggunakan statistik non-parametrik Mann-Whitney $U$ menunjukkan tidak ada perbedaan kepuasan kerja yang signifikan antara kelompok eksperimen dan kelompok kontrol $(Z=-0,033 ; p=0,974 ; p>0,05)$.
\end{abstract}

Kata kunci: Pelatihan kepemimpinan diri, kepuasan kerja 
Salah satu kenyataan yang tetap sama antara para karyawan di masa lampau dan masa kini adalah bahwa pekerjaan merupakan salah satu bagian utama dari kehidupannya dan salah satu dari sumber terbesar bagi kesenangan dan kedukaannya. Pada beberapa hal, pekerjaan mampu memberikan kepuasan kepada seseorang dengan adanya perasaan positif yang timbul atas penyelesain tugas dan pencapaian tujuan, namun pekerjaan dapat pula menjadi tekanan dan sumber bagi perasaan-perasaan negatif seseorang. Perasaan-perasaan negatif yang muncul ini, pada gilirannya dapat memengaruhi sikap dan perilaku karyawan (Riggio, 2003).

Terlepasdarikenyataan bahwabekerja menghabiskan banyak waktu, namun bekerja juga memberikan dasar finansial untuk menopang kebutuhan pokok maupun gaya hidup individu. Dengan demikian, salah satu pembahasan yang perlu digali berkaitan dengan pekerjaan adalah konteks kepuasannya (Tsigilis, Zachopulou \& Grammatikopoulos, 2006). Menurut Greenberg (1996), kepuasaan kerja adalah perasaan-perasaan individu yang merefleksikan sikapnya terhadap pekerjaan. Robbins dan Judge (2009) mengungkapkan bahwa istilah kepuasan kerja (job satisfaction) merujuk pada perasaan positif individu terhadap pekerjaannya, sebagai hasil evaluasi terhadap karakteristik pekerjaannya itu. Individu dengan tingkat kepuasan kerja tinggi menunjukkan perasaan positif terhadap pekerjaannya, sedangkan individu yang tidak puas dengan pekerjaannya menunjukkan perasaan negatif terhadap pekerjaan itu.

Kepuasan kerja memiliki banyak implikasi, baik bagi individu maupun organisasi. Kepuasan kerja merupakan hasil dari pertukaran antara tuntutan dan harapan organisasi, serta harapan pekerja dan tujuan pribadi. Pekerja dan organisasi memiliki hubungan yang timbal balik. Dalam hal ini organisasi menyediakan sarana bagi pekerja untuk memenuhi serangkaian kebutuhan dan untuk mewujudkan aspirasi pribadinya, sementara pekerja menyediakan organisasi dengan sumber daya sehingga dapat mencapai tujuan organisasi (Vallejo, Vallejo \& Parra, 2001).

Penelitian mengenai kepuasan kerja menunjukkan adanya korelasi positif yang signifikan antara kepuasan kerja dengan komitmen organisasional karyawan (Andolsek \& Stebe, 2004; Caykoylu, Egri, \& Havlovic, 2007; Salami, 2008). Lebih lanjut dijelaskan oleh Salami (2008) bahwa kepuasan kerja merefleksikan reaksi yang bersifat segera dari seorang individu terhadap pekerjaannya. Reaksireaksi ini memengaruhi perkembangan komitmen individu terhadap organisasi setelah pembentukan penilaian yang dilakukannya terhadap organisasi yang mempekerjakannya, nilai-nilainya, harapanharapan, dan masa depan individu tersebut di dalamnya. Dengan kata 
lain, seorang karyawan yang lebih puas dengan pekerjaannya adalah karyawan yang lebih berkomitmen terhadap organisasinya. Rendahnya kepuasan kerja juga diasosiasikan dengan tingginya intensi karyawan untuk pindah kerja (Chen, Chang, \& Yeh, 2004; Zeytinoglu dkk., 2007) dan burnout (Erdem dkk., 2008).

Menurut Riggio (2003), kepuasan kerja terdiri atas perasaan-perasaan dan sikap individu terhadap pekerjaannya. Semua aspek dari suatu pekerjaan tertentu yang dilakukan, baik dan buruk, positif dan negatif, akan berkontribusi terhadap perkembangan perasaan-perasaan kepuasan atau ketidakpuasan. Kreitner dan Kinicki (2003) berpendapat bahwa kepuasan kerja adalah suatu respon emosional terhadap berbagai aspek pekerjaan. Definisi ini mengindikasikan bahwa kepuasan kerja bukanlah suatu konsep tunggal. Sebaliknya, individu dapat relatif puas dengan satu aspek pekerjaannya dan tidak puas dengan salah satu atau lebih aspek yang lainnya.

Sejalan dengan pendapat di atas, penelitian longitudinal Peterson, Puia, dan Suess (2003) terhadap 365 karyawan perusahaan Amerika yang beroperasi di Meksiko menunjukkan bahwa kepuasan terhadap pekerjaan yang dilakukan, supervisi, hubungan antar-karyawan, upah, peluang promosi yang dimiliki, bagaimana supervisi dilakukan, dan persepsi karyawan mengenai status keuangan dan sosial perusahaan merupakan prediktor dari kepuasan kerja secara menyeluruh.
Berdasarkan hasil wawancara dengan pimpinan fakultas $X$ sebuah kampus swasta di Yogyakarta terungkap bahwa lebih dari setengah jumlah karyawan yang ada menunjukkan etos kerja yang belum maksimal bahkan rendah. Meskipun telah memahami dengan baik apa yang menjadi tugas dan wewenangnya, seringkali karyawan tidak dengan segera mengerjakan tugasnya kecuali setelah atasan mengingatkan. Akibatnya, beberapa kualitas pekerjaan karyawan menjadi tidak maksimal karena harus menyelesaikan tugastugasnya saat mulai mendekati tenggat waktu yang disediakan. Sementara itu, berdasarkan hasil wawancara terhadap karyawan diketahui bahwa tiga dari empat karyawan mengeluhkan sulitnya proses kenaikan pangkat (promosi), satu karyawan mengeluhkan tentang tunjangan yang diterimanya, satu orang mengeluhkan tentang komunikasi yang terbangun di dalam organisasi dan satu orang mengeluhkan tentang sulitnya aturan dan prosedur kerja yang ada. Menurut Robbins (1998), meninggalkan pekerjaan, mengeluh, membangkang, mencuri barang milik organisasi atau menghindari sebagian dari tanggungjawab pekerjaannya merupakan ekspresi dari ketidakpuasan karyawan. Permasalahan ketidakpuasan kerja ini tentu akan berdampak serius jika tidak diatasi secara tepat.

Hasil penelitian yang dilakukan oleh Saiti (2007) terhadap sejumlah guru di Yunani yang menemukan bahwa terdapat 
tujuh faktor utama yang memengaruhi kepuasan kerja, di antaranya adalah peran atasan dan iklim tempat kerja, imbalan atas usaha yang dilakukan, remunerasi, kondisi organisasi secara umum, serta perasaan individu mengenai pekerjaannya. Sementara itu faktor-faktor yang memengaruhi kepuasan kerja, menurut Sunarto (2003), setidaknya ada enam hal, yaitu: (1) kerja mental yang menantang, (2) imbalan yang pantas, (3) kondisi kerja yang mendukung, (4) rekan kerja yang suportif, (5) kesesuaian antara kepribadian dan pekerjaan, dan (6) disposisi genetik individual. Karyawan cenderung menyukai pekerjaan-pekerjaan yang memberinya kesempatan untuk menggunakan keterampilan dan kemampuannya dan menawarkan beragam tugas, kebebasan, dan umpan balik mengenai betapa baik pekerjaan yang telah dilakukannya. Karakteristik ini membuat kerja secara mental menantang. Pekerjaan yang secara mental kurang menantang akan menciptakan kebosanan, tetapi yang terlalu banyak menantang pun akan menciptakan frustrasi dan perasaan gagal. Pada kondisi tantangan yang sedang, kebanyakan karyawan akan mengalami kesenangan dan kepuasan. Selain itu, para karyawan juga menginginkan sistem upah dan kebijakan promosi yang dipersepsinya sebagai adil, tidak meragukan, dan segaris dengan pengharapannya. Bila upah dilihat sebagai adil yang didasarkan pada tuntutan pekerjaan, tingkat keterampilan individu, dan standar pengubahan komunitas, kemungkinan besar akan dihasilkan kepuasan. Tetapi kunci yang menautkan upah dengan kepuasan bukanlah jumlah mutlak yang dibayarkan, lebih penting lagi adalah persepsi keadilan. Oleh karena itu, individu yang mempersepsi bahwa keputusan promosi dibuat dengan cara yang adil, kemungkinan besar akan merasakan kepuasan dengan pekerjaannya.

Sementara itu, menurut Baron dan Greenberg (1990), faktor-faktor yang memengaruhi kepuasan kerja antara lain adalah: (1) prosedur atau kebijakan organisasi yang meliputi tipe sistem imbalan yang digunakan oleh organisasi dan kebijakan organisasi yang terkait dengan pertisipasi karyawan dalam keputusan-keputusan yang dibuat, (2) kualitas supervisi, (3) aspek spesifik atau setting dari pekerjaan yang terdiri atas beban kerja secara keseluruhan, variasi pekerjaan, model karakteristik pekerjaan dan lingkungan sosial, dan (4) karakter pribadi karyawan, di mana individu yang percaya dirinya mampu memengaruhi atau mengontrol hasil pekerjaannya sendiri, juga cenderung menunjukkan kepuasan kerja yang lebih tinggi daripada individu yang merasa hasil pekerjaannya di luar pengaruh dirinya sendiri.

Berdasarkan uraian tersebut, maka peneliti menggunakan pelatihan kepemimpinan diri sebagai upaya yang dilakukan untuk meningkatkan kepuasan kerja pada karyawan fakultas $X$ sebuah universitas swasta di Yogyakarta. 
Dalam bukunya, Mastering SelfLeadership, Empowering Yourself for Personal Excellence, Neck dan Manz (2007) mendefinisikan kepemimpinan diri sebagai sebuah proses saat individu mampu mengontrol perilakunya sendiri, memengaruhi dan memimpin dirinya sendiri melalui penggunaan serangkaian strategi perilaku dan kognitif tertentu. Konsep kepemimpinan diri ini menekankan pentingnya individu untuk mampu memimpin dan mengarahkan dirinya sendiri dalam rangka meningkatkan kapasitas dirinya.

Pelatihan sendiri merupakan sebuah upaya intervensi yang ditujukan untuk meningkatkan pencapaian tujuan organisasi melalui optimalisasi kinerja individuindividu dalam organisasi. Menurut Noe (2000), pelatihan merupakan sebuah prosedur yang direncanakan oleh perusahaan untuk memfasilitasi proses pembelajaran karyawan mengenai kompetensi yang dibutuhkan dalam pekerjaan. Kompetensi ini meliputi pengetahuan, keterampilan ataupun tingkah laku yang penting untuk kelancaran kerja karyawan. Tujuan pelatihan bagi para karyawan adalah untuk menguasai pengetahuan, keterampilan, dan tingkah laku yang menjadi program pelatihan yang kemudian dapat diaplikasikan dalam aktivitas kerja sehari-hari. Pelatihan kepemimpinan diri sendiri dipilih berdasarkan pendapat Baron dan Greenberg (1990) yang menyatakan bahwa individu yang percaya dirinya mampu memengaruhi atau mengontrol hasil pekerjaannya sendiri menunjukkan kepuasan kerja yang lebih tinggi daripada individu yang merasa hasil pekerjaannya di luar pengaruh dirinya sendiri. Pelatihan kepemimpinan diri juga didasarkan pada pendapat dari Tyilana (2005) yang mengungkapkan bahwa kepuasan atau ketidakpuasan kerja adalah sebuah kondisi yang kompleks, keadaan yang dinamis yang bisa disebabkan oleh banyak faktor. Beberapa faktor berasal dari dalam diri para karyawan (intra-personal) dan para karyawan tersebut memiliki sebuah kontrol langsung ataupun tidak langsung atau memiliki pengaruh terhadap faktorfaktor tersebut. Beberapa faktor yang lainnya berasal dari luar karyawan (ekstra-personal) dan karyawan tidak memiliki kontrol langsung ataupun tidak langsung atau tidak memiliki pengaruh terhadap faktor-faktor tersebut. Dengan demikian, maka sasaran dari pelatihan kepemimpinan diri adalah dunia yang terjadi dalam diri (intra-personal) para karyawan. Karena kepemimpinan diri ini merupakan sebuah proses saat individu mampu mengontrol perilakunya, memengaruhi, dan memimpin dirinya sendiri melalui penggunaan serangkaian strategi perilaku dan kognitif tertentu untuk mencapai perilaku dan kinerja yang diharapkan (Neck \& Manz, 2007).

Berakar pada beberapa teori yang terkait dengan regulasi-diri, kontroldiri, manajemen-diri, dan teori motivasi intrinsik, kepemimpinan diri beroperasi 
dalam teori sosial kognitif Bandura. pikiran dan perasaan terlibat dalam Teori sosial kognitif menjelaskan bahwa perilaku manusia secara tepat dijelaskan oleh hubungan timbal balik tiga arah antara pengaruh internal, pengaruh eksternal, dan perilaku (Neck \& Houghton, 2006). Lebih lanjut Neck, Nouri, dan Godwin (2003) mengungkapkan bahwa perilaku individu dalam organisasi tidak hanya dipengaruhi oleh lingkungan organisasi atau faktor eksternal, tetapi juga elemen individu dalam organisasi itu sendiri yang meliputi pengaturan-diri dari faktor kognitif.

Kepuasan kerja berkaitan dengan persepsi individu dan evaluasi pekerjaan, dan persepsi ini dipengaruhi oleh keadaan karyawan, termasuk kebutuhan, nilai dan pengharapan (Buitendach \& de Witte, 2005). Locke (Saari \& Judge, 2004) menyebutkan bahwa kepuasan kerja merupakan keadaan emosional yang menyenangkan atau positif yang dihasilkan dari penilaian pekerjaan atau pengalaman kerja. Lebih lanjut Saari dan Judge (2004) menjelaskan bahwa definisi tersebut secara implisit menjelaskan tentang pentingnya emosi atau perasaan, dan kognisi atau pikiran. Ketika individu berpikir, individu mempunyai perasaan tentang apa yang dipikirkan. Sebaliknya, ketika individu memiliki perasaan, individu tersebut berpikir tentang apa yang dirasakan. Kognisi dan perasaan memiliki kaitan yang erat, baik dalam psikologis, bahkan dalam konteks biologis. Jadi, ketika individu mengevaluasi pekerjaannya, menilai dan mempersepsi segala yang penting bagi dirinya, di mana hal ini selanjutnya menghasilkan kepuasan atau ketidakpuasan karyawan terhadap pekerjaannya. Pelatihan kepemimpinan diri sendiri pada prinsipnya bertujuan untuk mampu meningkatkan kapasitas diri individu dalam mengontrol, memotivasi, dan mengarahkan dirinya melalui serangkaian penggunaan strategi perilaku dan kognitif tertentu untuk menyikapi keadaan diri maupun lingkungannya (Neck \& Manz, 2007), sehingga kepuasan karyawan terhadap pekerjaannya pun dapat diperbaiki.

Hasil penelitian Roberts dan Foti (1996) terhadap sejumlah karyawan manufaktur menemukan bahwa interaksi antarakepemimpinandiridan strukturkerja mampu memengaruhi tingkat kepuasan kerja karyawan $\left(R^{2}=0,07, p<0,01\right)$. Para karyawan dengan kepemimpinan diri yang tinggi dan struktur kerja yang lebih bebas cenderung memiliki tingkat kepuasan kerja yang lebih tinggi. Dalam penelitian yang lain terhadap sejumlah karyawan sebuah maskapai penerbangan internasional komersial di Amerika terbukti bahwa strategi mental dalam pelatihan kepemimpinan diri mampu meningkatkan kepuasan kerja (Neck \& Manz, 1996). Dengan demikian, hasil ini menjadi salah satu landasan teoritis bahwa kepemimpinan diri merupakan salah satu faktor prediktif bagi kepuasan kerja. 
Secara umum, strategi kepemimpinan diri dibagi menjadi tiga kategori utama yaitu: (1) strategi perilaku terfokus, (2) strategi pemberian penghargaan alamiah, dan (3) strategi pola pikir konstruktif (Prussia dkk, 1998; Neck \& Manz, 2007).

Strategi pertama adalah strategi perilaku terfokus. Strategi perilaku terfokus ini dirancang untuk meningkatkan kemampuan mengatur kesadaran diri untuk mendapatkan pengelolaan perilaku yang benar pada tugas-tugas yang penting namun tidak menyenangkan. Berdasarkan pada teori kontrol diri dan manajemen diri, strategi perilaku terfokus dalam kepemimpinan diri ini terdiri atas observasi diri, penetapan tujuan-diri, penghargaan bagi diri sendiri, dan umpan balik atas koreksi diri. Observasi diri melibatkan pengujian individu atas perilakunya sendiri untuk meningkatkan kesadaran mengenai kapan dan mengapa perilaku tertentu terjadi. Melalui observasi diri seseorang dapat mengidentifikasi perilakuperilaku untuk diubah, dihilangkan, atau ditingkatkan. Peningkatan kesadaran perilaku ini merepresentasikan langkah awal menuju perubahan perilaku yang memungkinkan individu untuk lebih secara efektif menetapkan tujuan-tujuan dalam rangka memperbaiki performansi personal. Penetapan tujuan-diri ini, bersama dengan penghargaan bagi diri sendiri, dapat menjadi sangat efektif dalam meningkatkan perilaku-perilaku yang dibutuhkan bagi pencapaian tujuan (Neck \& Manz, 2007). Umpan balik atas koreksi diri juga sangat bermanfaat untuk membentuk perilaku yang diharapkan. Introspeksi atas kegagalan dan perilaku yang tidak diharapkan dalam kerangka yang positif akan lebih efektif dalam membentuk kembali perilaku-perilaku ini daripada penggunaan hukuman diri yang berlebihan yang melibatkan kritik-diri dan rasa bersalah (Neck \& Manz, 2007).

Penelitian Politis (2006) pada karyawan di sebuah perusahaan manufaktur di Australia membuktikan bahwa terdapat korelasi positif yang signifikan antara strategi perilaku terfokus dalam kepemimpinan diri dengan kepuasan kerja. Secara spesifik strategi perilaku terfokus dalam kepemimpinan diri, yaitu, observasi diri, hukuman diri, penghargaan terhadap diri sendiri, penetapan tujuan diri, dan latihan, memiliki hubungan positif yang signifikan dengan kepuasan kerja yang bersifat intrinsik dan ekstrinsik (kecuali latihan yang hanya berkorelasi positif dengan kepuasan kerja ekstrinsik saja).

Strategi kedua dalam kepemimpinan diri adalah strategi penghargaan alamiah. Strategi ini berfokus pada aspek-aspek menyenangkan yang melekat pada tugas atau aktivitas yang dilakukan dan dirancang untuk menciptakan situasi saat seseorang dimotivasi dan mendapatkan imbalan dari tugas atau aktivitas itu sendiri. Strategi pemberian penghargaan alamiah ini melibatkan dua pendekatan utama, yaitu membangun lebih banyak hal-hal yang menyenangkan dan bisa 
dinikmati dari sebuah tugas atau aktivitas sehingga nilai yang diperoleh dari tugas dan tugas itu sendiri secara alamiah menjadi sebuah penghargaan, dan membentuk persepsi seseorang terhadap sebuah aktivitas dengan berfokus pada aspek-aspek penghargaan alamiah yang melekat padanya (Neck \& Manz, 2007). Menurut Deci dan Tyan (Hooughton \& Yoho, 2005), kedua pendekatan ini cenderung untuk menekankan pada perasaan mampu dan determinasi diri, yang merupakan dua mekanisme utama dalam motivasi instrinsik.

Strategi terakhir adalah strategi pola pikir konstruktif. Strategi pola pikir konstruktif bekerja pada pengelolaan proses kognitif. Ada tiga alat utama untuk membentuk pola pikir, yaitu analisis diri dan perbaikan sistem keyakinan, imajeri mental atas hasil kerja yang sukses, dan bicara-diri yang positif. Pendayagunaan yang efektif dari strategi kognitif yang spesifik ini cenderung untuk memfasilitasi pembentukan pola pikir konstrukif dan kebiasaan cara pikir yang secara positif dapat meningkatkan performansi, seperti memandang suatu pekerjaan sebagai tantangan dibanding hambatan. Secara lebih spesifik, individu dapat menguji pola pikirnya untuk mengidentifikasi, mengkonfrontasi, dan menggantikan keyakinan dan asumsi-asumsi disfungsional dengan yang lebih rasional untuk memfasilitasi lebih banyak pola pikir konstruktif. Dengan cara yang sama, bicara diri yang negatif dan destruktif dapat diidentifikasi dan digantikan dengan bicara diri yang lebih positif dan konstruktif (Neck \& Manz, 1996, 2007). Bicara diri telah didefinisikan sebagai apa yang secara diam-diam dikatakan seseorang pada dirinya sendiri dan secara umum melibatkan evaluasi kognitif dan reaksi-reaksi pada dirinya sendiri maupun lingkungannya (Neck \& Manz, 1996, 2007). Sementara itu, imajeri mental terdiri atas sebuah ciptaan simbolik dan tertutup dari sebuah pengalaman atau tugas tanpa gerakan otot fisik yang tampak. Melalui imajeri mental, dimungkinkan untuk secara simbolik mengalami hasil perilaku awal sampai ke performansi aktual (Neck \& Manz, 1996), dan individu yang membayangkan kesuksesan dari sebuah aktivitas akan lebih mampu menunjukkan performansi yang sukses ketika dihadapkan pada tugas aktual (Neck \& Manz, 2007).

Strategi mental dalam kepemimpinan diri pernah dilatihkan Neck dan Manz (1996) kepada sejumlah karyawan sebuah maskapai penerbangan internasional komersial di Amerika yang baru saja dinyatakan bangkrut. Sebagai hasil dari situasi keuangan yang kritis ini, manajemen perusahaan memberhentikan 2.000 karyawannya dan mengurangi jumlah pesawat yang dimilikinya dari 115 pesawat menjadi hanya 100 pesawat. Sebagai konsekuensinya, banyak karyawan yang merasa ketakutan akan kehilangan pekerjaannya. Dalam pelatihan tersebut, peserta menerima instruksi untuk mendaya- 
gunakan strategi-strategi mental berikut ini untuk meningkatkan kinerjanya: (1) bicara diri, (2) imajeri mental, (3) pengelolaan keyakinan-keyakinan dan asumsi-asumsi, (4) pola-pola pikiran, dan (5) pencegahan munculnya kesalahan lagi (untuk memastikan pemeliharaan keterampilan yang telah dipelajari). Hasil penelitian menunjukkan bahwa rerata kepuasan kerja kelompok eksperimen yang mendapatkan pelatihan secara signifikan lebih tinggi $(M=15,542, t(46)=2,065, p<0,05$, $\left.\mathrm{W}^{2}=0,06\right)$ daripada kelompok kontrol $(M=13,042)$. Pelatihan ini juga mampu meningkatkan kinerja mental, efikasi diri, dan afeksi positif (antusiasme), dan menurunkan afeksi negatif (kegelisahan) karyawan. Bahkan setelah mendapatkan pelatihan ini, para karyawan memandang situasi kebangkrutan yang sedang melanda perusahaannya dengan cara yang lebih positif.
Serangkaian materi kepemimpinan diri dalam penelitian ini disajikan dengan metode belajar melakukan sesuatu, mengalami sesuatu, dan merasakan sesuatu. Pelatihan kepemimpinan diri bertujuan untuk meningkatkan kapasitas diri individu dalam mengontrol, memotivasi, dan mengarahkan dirinya melalui serangkaian penggunaan strategi perilaku dan kognitif tertentu untuk menyikapi keadaan diri maupun lingkungannya. Dengan mengaplikasikan pengetahuan dan keterampilan hasil pelatihan, diharapkan peserta memiliki kemampuan untuk mempergunakannya dalam konteks nyata pekerjaan sehingga mampu memimpin dirinya sendiri. Pada tahapan selanjutnya peserta yang dapat memimpin dirinya sendiri akan berdaya untuk melakukan segala upaya yang dapat membantunya merasa lebih puas atas pekerjaannya.

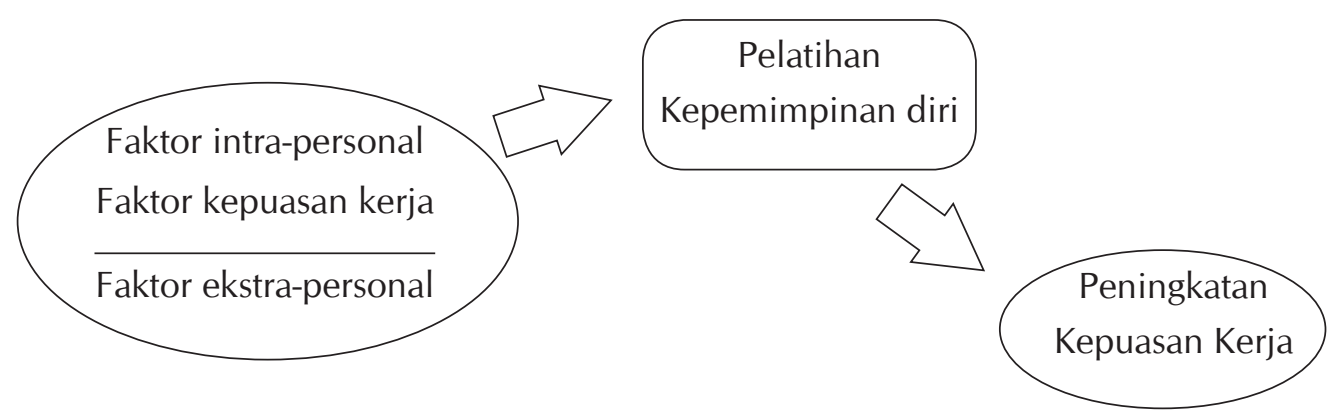

Gambar 1. Kerangka Berpikir Penelitian 
Secara spesifik, hipotesis dalam atas 11 subjek yang bersifat waitingpenelitian ini adalah bahwa pelatihan list, yaitu akan mendapatkan pelatihan kepemimpinan diri akan meningkatkan kepemimpinan diri setelah penelitian ini kepuasan kerja karyawan.

\section{METODE}

\section{Subjek Penelitian}

Subjek dalam penelitian ini adalah 22 karyawan non-akademik fakultas $\mathrm{X}$ pada salah satu kampus swasta di kota Yogyakarta. Kedua puluh dua subjek dibagi kedalam dua kelompok, yaitu kelompok eksperimen dan kelompok kontrol secara non-random. Kelompok eksperimen terdiri atas 11 subjek dan mendapatkan pelatihan kepemimpinan diri, sementara kelompok kontrol terdiri selesai. Sebelum dilakukan penelitian, subjek diminta untuk menandatangani lembar persetujuan kesediaan menjadi subjek penelitian.

\section{Desain Eksperimen}

Penelitian ini menggunakan eksperimen kuasi dengan desain the untreated control group design with prestest and posttest (Cook \& Campbell, 1979). Desain eksperimen kuasi ini digunakan karena eksperimen murni tidak memungkinkan untuk dilakukan dengan kondisi yang ada. Desain eksperimen dapat dilihat dalam gambar berikut:

\begin{tabular}{|c|c|c|c|}
\hline KE: & O1 & $X$ & $\mathrm{O} 2$ \\
\hline KK: & O1 & & $\mathrm{O} 2$ \\
\hline
\end{tabular}

Gambar 2. Desain Eksperimen

\section{Keterangan:}

$$
\begin{aligned}
\mathrm{O} 1 & =\text { Pengukuran protes } \\
\mathrm{X} & =\text { Pengukuran berupa pelatihan } \\
\mathrm{O} 2 & =\text { Pengukuran Pascates }
\end{aligned}
$$

\section{Pengukuran}

Kepuasan kerja diukur melalui skala kepuasan kerja hasil terjemahan dari Job Satisfaction Survey (JSS) yang disusun oleh Paul E. Spector (Crossman
\& Harris, 2006). Skala ini terdiri dari 36 butir yang merefleksikan sembilan segi dalam kepuasan kerja yaitu: (1) kepuasan terhadap upah dan kenaikan upah, (2) kepuasan terhadap kesempatan promosi, 
(3) kepuasan terhadap atasan, (4) kepuasan terhadap tunjangan, (5) kepuasan terhadap penghargaan untuk kinerja yang baik, (6) kepuasan dengan aturan dan prosedur, (7) kepuasan terhadap rekan kerja, (8) kepuasan terhadap tipe pekerjaan yang dilakukan, dan (9) kepuasan dengan komunikasi dalam organisasi.

Menurut Spector (Tyilana, 2005), JSS telah diuji reliabilitas konsistensi internal dan koefisien alphanya bergerak dari 0.60 untuk subskala rekan kerja sampai 0.90 untuk skala total. JSS menggunakan enam alternatif respon jawaban untuk masingmasing butir, respon bergerak dari "Sangat tidak setuju" (dibobot 1) sampai "Sangat setuju sekali" (dibobot 6).

Dalam penelitian ini, penulis tetap melakukan uji coba pada skala kepuasan kerja yang telah diterjemahkan. Proses seleksi butir aitem mempertimbangkan koefisien korelasi aitem-total. Aitem yang baik memiliki koefisien korelasi aitem-total di atas 0.3 (Azwar, 2003). Berdasarkan hasil analisis, ada sembilan aitem yang gugur, koefisien korelasi aitemtotal bergerak dari 0,304-0,762, dengan reliabilitas alpha Cronbach sebesar 0,939.

Kepemimpinan diri sendiri diukur dengan menggunakan Revised SelfLeadership Questionnaire (Houghtoun \& Neck, 2002) yang telah diterjemahkan. Skala ini terdiri atas 35 butir yang merefleksikan sembilan aspek dalam kepemimpinan diri, yaitu: (1) visualisasi kinerja yang sukses, (2) penetapan target diri, (3) bicara diri, (4) penghargaan bagi diri sendiri, (5) mengevaluasi keyakinan dan asumsi, (6) hukuman bagi diri sendiri, (7) observasi diri, (8) fokus pada penghargaan alamiah, dan (9) pengingat diri. Skala ini memiliki lima repson jawaban bergerak dari "Sangat tidak sesuai" (dibobot 1) sampai "Sangat sesuai" (dibobot 5).

Hasil analisis aitem dengan mempertimbangkan koefisien korelasi aitem-total di atas 0,3 (Azwar, 2003) menunjukkan ada lima butir aitem yang gugur. Koefisien korelasi aitem-total bergerak dari 0,326 0,768 dengan reliabilitas alpha Cronbach sebesar 0,936 .

\section{Prosedur Intervensi}

Perlakuan dalam penelitian ini diberikan dalam bentuk pelatihan kepemimpinan diri. Pelatihan ini menggunakan metode experiential learning (game, role play, diskusi), yaitu sebuah metode pelatihan yang membuat peserta belajar melalui pengalamannya.

Pelatihan kepemimpinan diri adalah serangkaian aktivitas sistematis yang dirancang untuk tujuan melatihkan strategi-strategi dalam kepemimpinan diri kepada peserta. Materi dalam pelatihan ini disusun berdasarkan pengembangan konsep dasar kepemimpinan diri oleh Neck dan Manz (2007) yang tertuang dalam buku Mastering Self-Leadership, Empowering Yourself for Personal Excellence maupun hasil penelitian-pene- 
litian terdahulu yang pernah dilakukan (Neck \& Houghton, 2006; Prussia, Anderson, \& Manz, 1998).

Pelatihan kepemimpinan diri ini merupakan pelatihan tujuh jam efektif (diberikan selama satu hari). Secara umum, pelatihan ini terbagi dalam lima sesi utama, yaitu: Sesi pertama dimulai dengan perkenalan untuk membangun hubungan baik antara pelatih dan peserta pelatihan dan membangkitkan minat peserta, serta memberikan pengantar kepada peserta berupa gambaran umum mengenai prinsip-prinsip dasar dalam kepemimpinan diri. Sesi kedua mengajarkan kepada peserta strategi perilaku terfokus dalam kepemimpinan diri, yaitu: (1) observasi diri, (2) penetapan tujuan diri, (3) penghargaan bagi diri sendiri, dan (4) hukuman bagi diri sendiri, serta melatihkan kepada peserta penggunaan strategi- strategi ini dalam kehidupan seharihari. Sesi ketiga mengajarkan kepada peserta strategi penghargaan alamiah dalam kepemimpinan diri dengan cara membangun lebih banyak hal-hal yang menyenangkan dan bisa dinikmati pada sebuah aktivitas/tugas yang diberikan sehingga tugas itu sendiri menjadi secara alamiah menjadi hadiah baginya. Selain itu, peserta juga dilatih memfokuskan perhatian untuk jauh dari aspek-aspek yang tidak menyenangkan dari sebuah tugas dan sebaliknya memfokuskannya kembali pada aspek-aspek penghargaan yang melekat dari tugas-tugas tersebut. Sesi akhir sesi materi pelatihan kepemimpinan diri dilakukan review untuk mengulas semua strategi yang ada dalam kepemimpinan diri sehingga pemahaman yang diperoleh peserta akan lebih komprehensif.

Tabel 1. Blue-print Modul Pelatihan Kepemimpinan diri

\section{Kegiatan}

Sesi pembuka
Tujuan dan Metode

Membangun kedekatan antara pelatih dan peserta, memberikan gambaran umum tentang materi dan tujuan pelatihan

Metode : game, presentasi 
Sesi I : Perilaku terfokus

1. Observasi

2. Self-reward

3. Self-punishment

4. Reminder
1. Meningkatkan kesadaran diri tentang kapan dan mengapa kita harus melakukan sebuah tindakan tertentu

2. Mampu memanfaatkan self-reward sebagai strategi untuk meningkatkan perilaku tertentu

3. Mampu memanfaatkan self-punishment sebagai strategi untuk mengurangi perilaku tertentu

4. Mampu memanfaatkan reminder untuk membantu agar tetap fokus pada tujuan yang ingin dicapai

Metode : presentasi, pengisian lembar kerja, diskusi

Sesi II : Penghargaan alamiah

1. Membangun lebih banyak hal-hal yang menyenangkan dan bisa dinikmati dari sebuah tugas atau aktivitas

2. Fokus pada aspek-aspek imbalan alamiah yang melekat pada sebuah aktivitas

Sesi III : Pola pikir konstruktif

1. Bicara diri

2. Imajeri mental

3. Pengelolaan pola pikir

Review
1. Mampu membangun lebih banyak hal-hal yang menyenangkan dan bisa dinikmati dari sebuah tugas atau aktivitas

2. Mampu membentuk persepsi seseorang terhadap sebuah aktivitas dengan berfokus pada aspek-aspek imbalan alamiah yang melekat pada sebuah aktivitas

Metode: presentasi, diskusi, pengisian lembar kerja

1. Mampu memanfaatkan bicara diri positif

2. Memiliki keterampilan untuk melakukan imajeri mental

3. Mampu mengelola pola pikir sehingga pikiranpikiran yang destruktif dapat digantikan dengan pola pikir yang konstruktif

Metode: menonton video, diskusi, presentasi, lembar kerja

Pengulangan kembali materi pelatihan secara singkat, peneguhan komitmen 
Adapun urutan proses pemberian intervensi dijelaskan berikut ini:

1. Satu minggu sebelum pelatihan kepemimpinan diri, semua subjek diminta untuk mengisi skala kepuasan kerja. Selanjutnya data dianalisis sehingga diperoleh gambaran tingkat kepuasan kerja karyawan. Mengingat jadwal kegiatan yang dimiliki oleh subjek penelitian maka pengelompokan partisipan ditentukan oleh pimpinan di tempat penelitian ini dilakukan. Kelompok eksperimen diberikan pelatihan kepemimpinan diri sedangkan kelompok kontrol tidak diberikan pelatihan.

2. Kelompok eksperimen diberikan pelatihan kepemimpinan diri selama tujuh jam efektif (diberikan selama satu hari). Pelatihan terbagi atas lima sesi, yaitu satu sesi pembukaan, tiga materi pelatihan kepemimpinan diri dan sesi review. Materi strategi perilaku terfokus bertujuan untuk meningkatkan kemampuan mengatur kesadaran diri untuk mendapatkan pengelolaan perilaku yang benar, yang melibatkan tugas-tugas yang penting namun tidak menyenangkan. Materi strategi penghargaan alamiah bertujuan agar peserta mampu menciptakan situasi saat dirinya dimotivasi dan mendapatkan imbalan dari halhal yang melekat pada tugas atau aktivitas yang dilakukannya. Materi pola pikir konstruktif diharapkan dapat meningkatkan kemampuan peserta dalam membentuk pola pikir yang konstruktif. Serangkaian materi ini disajikan dalam bentuk diskusi, ceramah, tayangan video, dan praktek. Pada akhir sesi pelatihan dilakukan review materi pelatihan untuk membantu peserta memahami strategi-strategi dalam kepemimpinan diri secara lebih komprehensif. Pelatihan ini diberikan oleh seorang pelatih berpengalaman. Pelatih didampingi oleh asisten pelatih yang bertugas untuk membantu kelancaran selama proses pelatihan.

3. Satu minggu setelah pelaksanaan pelatihan, dilakukan kembali pengumpulan data untuk keperluan evaluasi. Evaluasi terhadap pelaksanaan pelatihan ini dilakukan untuk mengetahui apakah pelaksanaan pelatihan benar-benar telah sesuai dengan tujuannya yaitu meningkatkan kompetensi kepemimpinan diri sehingga pada akhirnya dapat meningkatkan kepuasan kerja. Menurut Kirkpatrick (1996), ada empat level evaluasi pelatihan, yaitu (1) reaksi, untuk mengetahui apakah peserta menyukai program pelatihan. Evaluasi reaksi ini dilakukan setelah pelatihan diberikan, (2) pengetahuan, untuk mengetahui apa yang telah dipelajari peserta. Evaluasi pengetahuan dalam penelitian ini dilakukan hanya sesudah pelatihan diberikan, (3) perilaku, untuk mengetahui apakah perilaku peserta berubah setelah mengikuti pelatihan. 
Evaluasi perilaku dilakukan dengan menggunakan skala kepuasan kerja, (4) hasil, untuk mengetahui apakah perubahan perilaku peserta berpengaruh secara positif terhadap perusahaan/organisasi. Penelitian ini hanya melihat dampak pelatihan kepemimpinan diri pada level pertama, kedua dan ketiga, yaitu efek pelatihan pada peningkatan kompetensi kepemimpinan diri peserta yang pada akhirnya dapat membantunya untuk meningkatkan kepuasan kerja.

4. Tahap terakhir adalah melakukan analisis atas keseluruhan data yang diperoleh. Pelatihan kepemimpinan diri dapat dikatakan efektif apabila tingkat kepuasan kerja karyawan meningkat.

\section{Teknik Analisis Data}

Analisis data menggunakan statistik non-parametrik Mann-Whitney $U$ (Diekhoff, 1992) dengan tujuan untuk mengetahui apakah ada perbedaan kepuasan kerja yang signifikan antara kelompok kontrol dan kelompok eksperimen setelah diberi perlakuan.

\section{HASIL PENELITIAN}

\section{Deskripsi Statistik}

Berdasarkan hasil perhitungan statistika diketahui bahwa rerata kepuasan kerja kelompok eksperimen lebih tinggi daripada kelompok kontrol. Hasil selengkapnya dapat dilihat seperti pada Tabel 2.

Tabel 2. Perbandingan Skor Kepuasan Kerja Kelompok Eksperimen dan Kontrol

\begin{tabular}{lccccc}
\hline \multicolumn{1}{c}{ Kelompok } & N & $\begin{array}{c}\text { Rerata } \\
\text { Pre-test }\end{array}$ & $\begin{array}{c}\text { Rerata } \\
\text { Post-test }\end{array}$ & $\begin{array}{c}\text { Gained } \\
\text { Score }\end{array}$ & SD \\
\hline Eksperimen & 11 & 121,4545 & 121 & $-0,4545$ & 9,41662 \\
Kontrol & 11 & 113,5455 & 113,4545 & $-0,0909$ & 8,34811 \\
\hline
\end{tabular}

\section{HASIL UJI HIPOTESIS}

Hasil uji hipotesis dengan menggunakan statistik non-parametrik MannWhitney $U$ dapat dilihat pada Tabel 3 berikut ini:
Tabel 3. Analisis Gained Score Kepuasan Kerja

Kelompok Eksperimen dan Kontrol

\begin{tabular}{lc}
\hline & Gained-Scores \\
\hline Mann-Whitney U & 60 \\
Z & $-0,033$ \\
Asymp. Sig. (2-tailed) & 0,974 \\
\hline
\end{tabular}


Data di atas menunjukkan nilai $\mathrm{p}=$ 0,974 ( $p>0,05)$ artinya tidak terdapat perbedaan gained score yang signifikan antara kelompok kontrol dan kelompok eksperimen. Dengan demikian hipotesis penelitian yang menyatakan bahwa pelatihan kepemimpinan diri dapat meningkatkan kepuasan kerja karyawan tidak dapat diterima.

Pengukuran atas effect-size dengan rumus sebagai berikut ini (Field \& Hole, 2003):

$$
\begin{aligned}
& r=\frac{z}{\sqrt{N}} \\
& r=\frac{-0,33}{\sqrt{22}}=-0,007
\end{aligned}
$$

Merepresentasikan dampak yang sangat kecil, yang menunjukkan bahwa tidak ada perbedaan antara kelompok kontrol dan kelompok eksprerimen.

\section{PEMBAHASAN}

Hasil analisis data penelitian menunjukkan bahwa tidak terjadi peningkatan kepuasan kerja pada subjek di kelompok eksperimen. Sebaliknya, justru terjadi penurunan skor kepuasan kerja dengan rata-rata penurunan sebesar 0.4545 poin. Hasil gained score sebelum dan sesudah pelatihan pada kelompok eksperimen dan kelompok kontrol menunjukkan tidak ada perbedaan signifikan antara kelompok yang diberi pelatihan dengan kelompok yang tidak diberi pelatihan. Artinya pelatihan kepemimpinan diri yang diberikan kurang berperan secara optimal dalam meningkatkan kepuasan kerja. Dengan demikian hipotesis penelitian ini tidak dapat diterima.

Hasil penelitian ini tidak sejalan dengan hasil yang diperoleh Neck dan Manz (1996). Pelatihan kepemimpinan diri yang dilakukan oleh Neck dan Manz (1996) memang lebih berfokus hanya pada strategi pola pikir konstruktif (mental) dalam kepemimpinan diri dan terbukti mampu meningkatkan kepuasan kerja karyawan perusahaan maksapai penerbangan yang sedang terancam bangkrut. Sementara penelitian ini menggunakan ketiga strategi dalam kepemimpinan diri. Penggunaan ketiga strategi kepemimpinan diri dalam pelatihan pada penelitian ini lebih disebabkan alasan sebagai berikut: (1) strategi perilaku terfokus diharapkan mampu memfasilitasi peserta agar dapat berfokus pada perilaku yang dapat mendukung penyelesaian pekerjaannya mengingat selama ini karyawan di fakultas $X$ sering menunda penyelesaian tugasnya, (2) strategi penghargaan alamiah diharapkan mampu membantu peserta untuk lebih bahagia karena menemukan hal-hal menyenangkan yang melekat pada pekerjaannya. Sebab berdasarkan dari hasil wawancara tampak bahwa hal yang dikeluhkan karyawan di fakultas X lebih banyak terkait dengan promosi yang lebih sulit untuk diberikan intervensi karena melibatkan sistem, (3) strategi pola pikir konstruktif diharapkan 
mampu membantu peserta untuk lebih positif dalam memandang situasi yang dialaminya. Penggunaan ketiga strategi kepemimpinan diri ini tentu saja memberi konsekuensi bahwa materi yang harus diterima dan diserap oleh peserta pelatihan menjadi lebih banyak (jika dibandingkan penelitian sebelumnya).

Selain itu, penelitian Neck dan Manz (1996) memerlukan pengukuran berulang dan dilaksanakan 2 jam x 6 pertemuan selama enam minggu. Pengukuran juga dilakukan setelah kelompok kontrol mendapatkan perlakuan. Sementara penelitian yang dilakukan di fakultas $X$ ini menggunakan desain untreated control group design with pre-test and posttest hanya dengan satu kali pemberian perlakuan serta satu kali pengukuran setelah pemberian perlakuan dan hanya berjarak satu minggu setelah pemberian perlakuan. Dengan kondisi pengukuran yang hanya berjarak sangat pendek ini dan durasi pelatihan 7 jam yang dilaksanakan dalam satu hari dimungkinkan peserta belum sepenuhnya memiliki waktu untuk mengaplikasikan pengetahuan dan keterampilan yang telah diperoleh dari pelatihan tersebut ke dalam kehidupan nyata di keseharian pekerjaan. Dugaan peneliti ini diperkuat dengan pendapat Silberman (1998) yang mengatakan bahwa untuk mengukur efektivitas pelatihan, paling tidak perlu diberi waktu tenggang selama sedikitnya empat minggu untuk memberi kesempatan pada para peserta untuk mengaplikasikan hal-hal yang didapatkan pada saat pelatihan di tempat kerja. Kondisi ini menurut peneliti semakin diperkuat dengan karakter dasar dari konsep kepemimpinan diri.

Menurut Neck dan Houghton (2006), kepemimpinan diri bekerja dalam landasan motivasi intrinsik khususnya teori evaluasi kognitif. Teori evaluasi kognitif menyebutkan bahwa kebutuhan akan rasa mampu dan kebutuhan akan kehendak diri adalah mekanisme utama yang mendorong motivasi instrinsik. Kebutuhan rasa mampu meliputi kebutuhan seseorang untuk berlatih dan mengembangkan kemampuan, sementara kebutuhan kehendak diri meliputi kebutuhan untuk merasa bebas dari tekanan dari luar yang dipersepsi mengikatnya. Teori evaluasi kognitif berpendapat bahwa individu akan mencari untuk menemukan dan mengatasi tantangan dalam sebuah usaha untuk meningkatkan perasaan mampu dan kehendak diri. Perasaan mampu dan kontrol diri (misalnya kehendak diri) adalah bagian utama dari konseptualisasi penghargaan alamiah dalam kepemimpinan diri. Sifat dasar dari kepemimpinan diri ini tentu menjadi tantangan tersendiri dalam penerapannya di subjek dalam penelitian ini. Seperti yang diungkap dalam penggalian awal data penelitian, subjek dalam penelitian ini memiliki kecenderungan motivasi ekstrinsik yang jauh lebih besar yang ditunjukkan dengan kebiasaan pelaksanaan kerja yang baru dimulai 
apabila pimpinan sudah memberi teguran. Kondisi ini dimungkinkan menjadi penyebab utama penerapan kepemimpinan diri pada kelompok kontrol membutuhkan waktu yang relatif jauh lebih panjang.

Jumlah subjek yang sedikit juga ikut andil memengaruhi hasil analisis statistik yang tidak signifikan. Myers dan Hansen (2002) menyatakan bahwa perlakuan yang diberikan akan sulit memberikan efek yang signifikan jika jumlah sampel sedikit. Hal ini dapat dilihat dari jumlah subjek penelitian yang telah dilakukan oleh para peneliti sebelumnya. Jumlah subjek dalam penelitian Neck dan Manz (1996) adalah 48 orang sementara subjek dalam penelitian ini kurang dari separuhnya, yaitu 22 orang.

Padasisilain, pelatihankepemimpinan diri ini dinilai peserta pelatihan bermanfaat baginya. Peserta merasa puas karena pelatihan yang diberikan dapat memberi pengetahuan baru dan membantunya lebih bersemangat melaksanakan tugasnya. Kelebihan pelatihan ini mampu mendorong peserta untuk lebih mampu memandang situasi kerja dari sisi positif dan penyajian materi sistematis sehingga memudahkan peserta mengikuti alur pelatihan. Berdasarkan evaluasi pelatihan baik dari peserta maupun dari pengamat, pelatih dinilai mampu menghidupkan suasana pelatihan sehingga peserta tidak merasa bosan dan sebaliknya sangat tertarik untuk mendengarkan penjelasanpenjelasan dari pelatih. Evaluasi dari sisi proses penyelenggaraan pelatihan adalah fasilitas tempat pelatihan memadai dengan didukung oleh peralatan-peralatan seperti viewer, papan tulis, pendingin, dan lain-lain. Pendapat peserta pelatihan yang didapat dari kolom komentar umumnya menyatakan bahwa pelatihan kepemimpinan diri yang diberikan sangat bermanfaat bagi pengembangan diri serta perlu untuk secara rutin diberikan.

Adapun kelemahan-kelemahan yang terdapat dalam penelitian ini antara lain: Pertama, peneliti tidak melakukan cek manipulasi sehingga tidak diketahui perkembangan pengetahuan kepemimpinan diri pada peserta. Kedua, penelitian ini melakukan pengukuran terhadap kepuasan kerja hanya seminggu setelah pelatihan diberikan. Pendeknya masa antara pengukuran dengan pemberian intervensi ini disebabkan jadwal peserta yang sangat padat pada bulan dilakukannya penelitian sehingga tidak memungkinkan dilakukan pemberian tugas lanjutan bagi para peserta untuk menerapkan hasil pelatihan secara terstruktur.

\section{SIMPULAN DAN SARAN}

\section{Simpulan}

Berdasarkan hasil penelitian dapat disimpulkan bahwa pelatihan kepemimpinan diri dalam penelitian ini tidak mampu meningkatkan kepuasan kerja karyawan. Hal ini disebabkan oleh beberapa faktor: 
1. Ketiga strategi kepemimpinan diri digunakan sekaligus dalam pelatihan ini sehingga beban materi pelatihan yang harus diserap oleh peserta sangat banyak sementara pelatihan ini hanya dilakukan dalam satu hari. Berbeda dengan penelitian sebelumnya yang hanya menggunakan salah satu strategi dalam kepemimpinan diri, yaitu pola pikir konstruktif.

2. Pelatihan yang dilakukan sulit memberikan peranan yang signifikan terhadap kepuasan kerja karena kondisi jumlah subjek penelitian yang sedikit.

\section{Saran}

Saran Untuk Praktisi. Penelitian ini tidak berhasil membuktikan bahwa kepemimpinan diri dapat meningkatkan kepuasan kerja. Oleh karena itu, para praktisi yang ingin meningkatkan kepuasan kerja bagi individu dalam organisasi disarankan menggunakan pendekatan lain yang lebih komprehensif sebab kepemimpinan diri hanya membidik faktor-faktor intra-personal dalam kepuasan kerja.

Saran Untuk Peneliti Selanjutnya. Beberapa hal yang perlu dilakukan untuk perbaikan terhadap penelitian tentang pengaruh pelatihan kepemimpinan diri ini antara lain adalah sebagai berikut:

1. Pelatihan sebaiknya dilakukan dengan merujuk pada penelitian sebelumnya, yaitu dilakukan dalam durasi yang lebih pendek namun berlangsung selama beberapa pertemuan. Hal ini penting untuk membantu subjek dalam proses penyerapan materi pelatihan, terutama apabila semua strategi dalam kepemimpinan diri akan dilatihkan.

2. Melakukan penambahan sesi pembuatan rencana aksi dalam materi pelatihan. Sesi ini menjadi hal yang penting untuk membantu subjek lebih mudah mengaplikasikan pengetahuan dan keterampilan kepemimpinan diri yang telah diperolehnya dari pelatihan ke dalam kehidupan kerja keseharian. Selanjutnya tiga sampai empat minggu setelah penerapan rencana aksi dilakukan evaluasi atas pelaksanaan rencana aksi tersebut. Pada sesi ini peserta akan diajak untuk mendiskusikan hambatan yang mungkin ditemui dalam pelaksanaan rencana aksi tersebut sehingga dapat dirumuskan solusi atas permasalahan tersebut.

3. Penelitian selanjutnya diharapkan dapat melakukan cek manipulasi dengan melakukan pengukuran terhadap kepemimpinan diri bukan hanya setelah pelatihan namun juga sebelum pelatihan untuk memastikan bahwa apabila terjadi peningkatan kepuasan kerja maka hal tersebut semata-mata karena intervensi (pelatihan kepemimpinan diri) yang diberikan. 
4. Meningkatkan frekuensi pengukuran terhadap kepemimpinan diri dan kepuasan kerja (misalnya pada setiap minggu) serta periode waktu pengukuran yang lebih panjang (misalnya dalam rentang waktu 3 bulan atau lebih). Dengan begitu dapat diketahui secara lebih lengkap bagaimana perkembangan kompetensi kepemimpinan diri dan kepuasan kerja.

\section{DAFTAR PUSTAKA}

Andolsek, D. M., \& Stebe, J. (2004). Multinational perpectives on work values and commitment. International Journal of Cross Cultural Management, 4 (2), 181 - 209.

Baron, R. A., \& Greenberg, J. (1990). Behavior in organizations. Understanding and managing the human side of work. Massachussetts: Allyn and Bacon

Buitendach, J., \& De Witte, H. (2005). Job insecurity, extrinsic and intrinsic job satisfaction and affective organisational commitment of maintenance workers in a parastatal. South African Journal of Business Management, 36(2), 27-37.

Caykoylu, S., Egri, C. P., \& Havlovic, S. (2007). Organizational commitment across different employee groups. The Bussiness Review Cambridge, 8, $191-197$.
Chen, T., Chang, P., \& Yeh, C. (2004). A study of career needs, career development programs, job satisfaction, and the turnover intentions of $R$ \& D personnel. Career Development International, 9(4/5), 424 - 437.

Cook, T. D., \& Campbell, D. T. (1979). Quasi Experimentation: Designs and analysis issues for field settings. Boston: Houghton Miffin Company.

Crossman, A., \& Harris, P. (2006). Job satisfaction of secondary school teachers. Educational Management Administration Leadership, 34(1), $29-46$.

Diekhoff, G. (1992). Statistic for the social and behavioral sciences, univariate bivariate multivariate. Dubuque: Wm C. Brown Publishers.

Erdem, R., Rahman, S., Avci, L., Senoglu, B., Firat, G. (2008). Investigating job satisfaction and burnout levels of the persons working for hospitals at city center of Elaziğ Turkey. Journal of Applied Sciences Research, 4(2), $188-201$.

Field, A. \& Hole, G. 2003. How to design and report experiments. London: Sage Publications Ltd.

Greenberg, J. (1996). Managing behavior in organizations. New Jersey: Prentice-Hall, Inc. 
Houghton, J. D., \& Neck, C. (2002). The revised self-leadership questionnaire. Testing a hierarchical factor structure for self-leadership. Journal of Managerial Psychology, 17(8), $672-691$.

Houghton, J. D., \& Yoho, S. K. (2005). Toward a contingency model of leadership and psychological empowerment: When should self-leadership be encouraged? Journal of Leadership and Organizational Studies, 11(4), $65-83$.

Kirkpatrick, D.L. (1996). Evaluating training programs. San Francisco: BerretKoehler Publishers.

Kreitner, R., \& Kinicki, A. (2003). Organizational behavior. New York: McGraw-Hill Companies, Inc.

Myers, A. \& Hansen, C. H. (2002). Experimental psychology, (5th ed.). Pacific Groves: Wadsworth.

Neck, C. P., \& Houghton J. D. (2006). Two decades of self-leadership theory and research. Journal of Managerial Psychology, 21, 270 - 295.

Neck, C. P., \& Manz, C. C. (1996). Thought self-leadership: the impact of mental strategies training on employee cognition, behavior, and affect. Journal of Organizational Behavior, 17, 445 $-467$.

Neck, C. P., \& Manz, C. C. (2007). Mastering self-leadership, empowering yourself for personal excellence (4th edition). New Jersey: Person Prentice-Hall.

Peterson, D. K., Puia, G. M., \& Suess, F. R. (2003). Yo tengo la camiseta (I have the shirt on): An exploration of job satisfaction and commitment among workers in Mexico. Journal of Leadership and Organizational Studies, 10(2), $73-88$.

Politis, J. D. (2006). Self-leadership behavioral-focused strategies and team performance: The mediating influence of job satisfaction. Leadership and Organizational Development, 27, $203-216$.

Prussia, G. E., Anderson, J. S., \& Manz, C. C. (1998). Self-leadership and performance outcomes: the mediating influence of self-efficacy. Journal of Organizational behavior, 19, 523 $-538$.

Riggio, R. E. (2003). Introduction to industrial/organizational psychology. New Jersey: Pearson Education, Inc.

Roberts, H. E. \& Foti, R. J. (1996). Evaluating the interaction between selfleadership and work structure in predicting job satisfaction. Journal of Business and Psychology, 12(3), $257-267$.

Robbins, S. P. (1998) Organizational behavior. concepts, controversies, applications (8th. Ed). New Jersey: Prentice Hall 
Robbins, S.P. \& Judge, T.A. (2009). Organizational behavior. New Jersey: Pearson Education, Inc.

Saari, L. M \& Judge, T. A. (2004). Employee attitudes and job satisfaction. Human Resource Management, 43(4), 395-407.

Saiti, A. (2007). Main factors of job satisfaction among primary school educators: factor analysis of the Greek reality. Management in Education, 21(1), $28-32$.

Salami, S. O. (2008). Demographic and psychological factors predicting organizational commitment among industrial workers. Antropologist, 10(1), $31-38$.

Silberman, M. (1998). Active training. San Fransisco: John Wiley \& sons, Inc.

Sunarto. (2003). Perilaku organisasi. Yogyakarta: Penerbit Amus.
Tsigilis, N., Zachopoulou, E., \& Grammatikopoulos, V. (2006). Job satisfaction and burnout among Greek early educators: A comparison between public and private sector employees. Educational Research and Review, 1(8), 256-261.

Tyilana, X. E. (2005). The impact of motivation on job satisfaction amongst employees of a national broadcaster. Dissertation (unpublished). Faculty of Management, University of Johannesburg.

Vallejo, R. D., Vallejo, J. A. D. \& Parra, S. O. (2001). Job satisfaction in banking workers. Psicothema, 13 (4), 629-635.

Zeytinoglu, I. U., Denton, M., Davies, S., Baumann, A., Blythe, J., \& Boos, L. (2007). Deteriorated external work environment, heavy workload and nurses' job satisfaction and turnover intention. Canadian Public Policy Analyse De Politic, 23, 31 - 47. 